\title{
An empirical study to measure the effects of various factors on operating loss
}

\author{
Mohammad Khodaei Valahzaghard ${ }^{\mathrm{a}^{*}}$, Maryam Khalili Araghi ${ }^{\mathrm{b}}$, Seyyed Mahmoud Golampour \\ Papkiyadeh $^{\mathrm{b}}$ and Saeeid Khodaei Valahzaghard ${ }^{\mathrm{c}}$
}

\begin{abstract}
${ }^{a}$ Assist.Prof. \& Faculty Member, Department of Accounting, School of Management and Human Sciences,Tehran North Branch, Islamic Azad University (IAU), Tehran, Iran

${ }^{b}$ Assist. Prof. \& Faculty Member, Department of Management, School of Management and Economics, Tehran Science and Research Branch, Islamic Azad University (IAU), Iran

${ }^{c}$ M.A. Student, Department of Management, School of Management and Economics, Tehran Science and Research Branch, Islamic Azad University (IAU), Iran

${ }^{c}$ M.A. Student, Department of Management, School of Management and Human Sciences, Tehran North Branch, Islamic Azad University (IAU), Tehran, Iran

A R T I C L E I N F O

Article history:

Received March 14, 2012

Received in Revised form

June, 2, 2012

Accepted 22 June 2012

Available online

June 232012

Keywords:

Operational Risk

Basel II

Bank Mellat

A B S T R A C T

In this paper, we present an empirical investigation to measure the effects of various factors on operating loss in one of major Iranian banks called Bank Mellat. The proposed study of this paper uses a standard questionnaire and distributes it among 57 people who are mainly in top management levels. The questions are categorized into five groups including events related to the processes and methods, events outside the organization, related events within the organization and business disruptions and system failure. The results of our survey confirm that the loss associated with events related to the processes and methods increases operating risk meaningfully, the loss associated with business disruptions and system failure increases operating risk meaningfully and the loss associated with related events within the organization increases operating risk meaningfully. However, our survey do not confirm that the loss associated with events outside the organization increase operating, risk meaningfully. Finally, the preliminary survey of our analysis shows that there is not enough evidence to believe that the effects of business disruption and internal affairs are significantly different from the other event.
\end{abstract}

\section{Introduction}

The primary objective of the new Basel capital accord (Basel II) was to create an international standard for banking regulators to control how much money banks require setting aside to protect against the types of financial and operational risks banks and the whole economy face. One focus was to keep enough consistency of regulations so that this would not become a source of competitive inequality amongst internationally active banks. It is believed that such an international standard would help protect the international financial system from the types of problems that might arise should a major bank or a series of banks collapse. In theory, Basel II tries to build this by setting up

* Corresponding author. Tel: +98912-3443139 
risk and capital management needs designed to ensure that a bank has enough capital for the risk the bank exposes itself to through its lending and investment practices. During the past few years, there have been tremendous works devoted to this method to understand how effective this method is.

Basel II promises standards for measurement of financial and operational risk for the banking industry. However, the approach to such risk measurement has been criticized in the literature, raising doubts concerning the efficiencies of Basel II. Wahlström (2009) in an assignment used data from 25 semi-structured interviews with banking staff in four Swedish commercial banks and reported that Basel II is well established but there are still some concerns that this method may intentionally impact banks' activities. Although Basel II is supported by banking staff who work directly with risk measurement, the advantage of using such method is still questioned by banking staff in operations. This difference between these two groups may be explained in association with variations in their respective frames of reference. Wahlström recommends for addressing this schism within banks to encourage a wider debate about the different approaches for implementation of Basel II.

Xie et al. (2011) explained that drawing specific reserve separately for operational risk is one of the primary requirements of Basel II technique. Since 1990, as serious loss incidents in operation risk often occurred all over the world, operational risk has been taken account into the risk management framework for the first time in Basel technique. They analyzed the data of Chinese commercial bank operational risk by Monte Carlo simulation, empirically and reported that China commercial bank should allocate 15 billon capital for its operational risk while the capital reserve fund rate is about 4.79\%. Feng-ge and Ping (2012) discussed that operational risks in Decision Engineering absorb so much interest from the bank industry that Basel Committee includes it in the risk capital and considers it as a part of inspection criteria. Therefore, they used conditional-value-at-risk model based on peak value method of extreme value theory to measure the operational risks. Based on the results, theu offered different strategies such as the provision of risk reserves, the allocation of economic capital, insurance and outsourcing to control and manage operational risks.

Chavez-Demoulin et al. (2006) explained that because of the new regulatory guidelines known as Basel II for banking and Solvency 2 for insurance, the financial industry was looking for qualitative and quantitative techniques for operational risk. Whereas a full quantitative technique may never be obtained, they offered some techniques from probability and statistics, which could be used in any quantitative modeling environment. Chateau et al. (2009) computed the bank's capital charge for credit and operational risks of loan commitments at Basel-2 fixed audit date in three steps. Peters et al. (2011) argued that under the Basel II standards, the Operational Risk (OpRisk) advanced measurement approach could not be prescriptive regarding the class of statistical model utilized to undertake capital estimation. They derived a new class of doubly stochastic-stable famil models, which is able to capture the heavy tailed loss processes typical of OpRisk. More specifically, they developed models of the annual loss processes in two scenarios where the first one considers the loss processes with a stochastic intensity parameter and the second one considers discretization of the annual loss processes into monthly increments with dependent time increments. They also derived analytic results for the annual loss distribution density and distribution under each of these models and studied their properties. Aquaro et al. (2010) presented a system for operational risk management based on the computational paradigm of Bayesian Networks, which permits the construction of a Bayesian Network targeted for each bank and considers a straightforward way the correlations among various processes of the bank. They validated the method on synthetic time series and emphesesized that the method could be used for the practical implementation in a mid or small sized bank, since it contains a small effect on the organizational structure of a bank and needs an investment in human resources, which is limited to the computational area.

Jiménez-Rodríguez et al. (2011) explain that Basel II generates a minimum threshold of 10,000 Euros for operational losses when estimating regulatory capital for financial firms. However, this recommendation is not obligatory for the bank industry and banks are permitted to use internal 
thresholds discretionally. Therefore, Jiménez-Rodríguez et al. (2011) analyzed the potential effect that the selection of a specific threshold could possibly have on the final estimation of the capital charge for covering operational risk, adopting a critical perspective. They used the internal operational losses database (IOLD) provided by a Spanish Saving Bank to calculate the loss distribution approach (LDA) for various modeling thresholds. They reported that the opportunity cost in which banks can face depends on the internal threshold chosen.

The proposed study of this paper uses Basel II technique to measure operational risk for one of the biggest banks in Iran called Mellat. The organization of this paper first presents details of our sampling and data validation in section 2 as well as the description of hypotheses. Section 3 presents the results of our study and finally concluding remarks are given in the last to summarize the contribution of the paper.

\section{The proposed method}

The proposed study of this paper uses a standard questionnaire consists of 50 questions dedicated to Basel II technique and all questions are formed in Likert scale from one to five. There are four variables associated with the proposed study of this paper including events related to the processes and methods $\left(x_{1}\right)$, events outside the organization $\left(x_{2}\right)$, related events within the organization $\left(x_{3}\right)$ and business disruptions and system failure $\left(x_{4}\right)$. Table 1 shows variables and their categories, the number of responses gathered, the number of questions and Cronbach alpha.

\section{Table 1}

Cronbach alpha or different questions of the survey

\begin{tabular}{|c|c|c|c|c|}
\hline Variable & Category & $\begin{array}{l}\text { Responses } \\
\text { gathered }\end{array}$ & $\begin{array}{l}\text { Number of } \\
\text { questions }\end{array}$ & $\begin{array}{l}\text { Cronbach } \\
\text { alpha }\end{array}$ \\
\hline \multirow{5}{*}{$\begin{array}{l}\text { Relative } \\
\text { importance }\end{array}$} & Events related to the processes and methods & 57 & 12 & 0.897 \\
\hline & Events outside the organization & 57 & 8 & 0.940 \\
\hline & Related events within the organization & 57 & 24 & 0.982 \\
\hline & Business disruptions and system failure & 57 & 6 & 0.902 \\
\hline & Summary & 57 & 50 & 0.984 \\
\hline \multirow{5}{*}{$\begin{array}{l}\text { Likely } \\
\text { to repeat }\end{array}$} & Events related to the processes and methods & 57 & 12 & 0.905 \\
\hline & Events outside the organization & 57 & 8 & 0.898 \\
\hline & Related events within the organization & 57 & 24 & 0.954 \\
\hline & Business disruptions and system failure & 57 & 6 & 0.807 \\
\hline & Summary & 57 & 50 & 0.972 \\
\hline
\end{tabular}

Table 2 shows details of 57 participants in our survey.

Table 2

Personal characteristics of the participants

\begin{tabular}{|c|c|c|c|c|}
\hline & & Number & Percentage & Mode \\
\hline \multirow[b]{2}{*}{ Sex } & Male & 50 & 87.7 & Male \\
\hline & Female & 7 & 12.3 & \\
\hline \multirow{4}{*}{ Education(Years) } & 12 & 19 & 33.3 & \\
\hline & 14 & 5 & 8.8 & 16(Bachelour) \\
\hline & 16 & 29 & 50.9 & \\
\hline & 18 & 4 & 7.0 & \\
\hline \multirow{3}{*}{ Age (Years) } & $<38$ & 17 & 29.8 & \\
\hline & $39-43$ & 25 & 43.9 & $39-43$ \\
\hline & $>43$ & 15 & 26.3 & \\
\hline \multirow[b]{2}{*}{ Position } & Head of Branch & 31 & 54.4 & Head of Branch \\
\hline & Deputy Branch & 26 & 45.6 & \\
\hline \multirow{3}{*}{ Experience (Years) } & $<=15$ & 13 & 22.8 & \\
\hline & $16-20$ & 22 & 38.6 & 2Modes:16-20, <20 \\
\hline & $>20$ & 22 & 38.6 & \\
\hline
\end{tabular}


Table 3

Statistical observation on mean, standard deviation, skew strain for each variable

\begin{tabular}{cccccccccc}
\hline \multirow{2}{*}{ Var } & \multirow{2}{*}{ Number } & Mean & Standard deviation & Variance & Skew & Strain & Skew & Strain \\
\hline$x_{1}$ & 57 & 11.232 & 4.701 & 22.097 & 0.706 & -0.230 & 2.232 & -0.369 \\
$x_{2}$ & 57 & 9.680 & 4.975 & 24.753 & 0.385 & -0.359 & 1.217 & -0.576 \\
$x_{3}$ & 57 & 10.433 & 4.904 & 24.049 & 0.782 & -0.149 & 2.473 & -0.239 \\
$x_{4}$ & 57 & 11.015 & 4.691 & 22.003 & 0.544 & -0.588 & 1.719 & -0.943 \\
\hline
\end{tabular}

In order to examine whether the data are normally distributed we need to perform One-Sample Kolmogorov-Smirnov Test, where the null hypothesis is that the distribution is normal and alternative hypothesis is that the distribution of the data is not normal. The results of our test are summarized in Table 4 as follows,

\section{Table 4}

One-Sample Kolmogorov-Smirnov Test (The significance level is five percent)

\begin{tabular}{lllrcl}
\hline Var. & Number & Mean & z-statistic & P-value & Result \\
\hline$x_{1}$ & 57 & 11.232 & .876 & .427 & Normally distributed \\
$x_{2}$ & 57 & 9.680 & .629 & .823 & Normally distributed \\
$x_{3}$ & 57 & 10.433 & .987 & .284 & Normally distributed \\
$x_{4}$ & 57 & 11.015 & .788 & .565 & Normally distributed \\
\hline
\end{tabular}

As we can observe, we do not have enough evidence to reject the null hypothesis, which brings us to conclude that the data are normally distributed.

\section{The results}

In this section, we present some of the results of testing six hypotheses.

\subsection{First hypothesis: The loss associated with events related to the processes and methods increases operating risk meaningfully.}

In this survey, we have multiplied the relative importance by the possibility of occurrence and the average scaling for each part is three. Therefore, we consider a theoretical value of nine for all hypotheses. Therefore, we have,

$$
\left\{\begin{array}{l}
H_{0}: \text { Mean } \leq 9 \\
H_{1}: \text { Mean }>9
\end{array}\right.
$$

In our survey, t-student value is 3.59, which is well above the critical value of 1.96 when the level of significance is five percent. Therefore, null hypothesis is rejected and we can conclude that loss because of events related to the processes and methods increases operating risk, significantly.

\subsection{Second hypothesis: The loss associated with business disruptions and system failure increases operating risk meaningfully.}

With similar argument we presented in the previous hypothesis we can compute t-student value, which is 3.24>1.96 and this means that we can reject the null hypothesis when the level of significance is five percent. Therefore, null hypothesis is rejected and we can conclude that loss because of business disruptions and system failure increases operating risk, significantly. 
3.3. Third hypothesis: The loss associated with events outside the organization increases operating risk meaningfully.

Again, we can compute t-student value, which is $1.04>1.96$ and this means that we cannot reject the null hypothesis when the level of significance is five percent. Therefore, null hypothesis is accepted and we can conclude that loss because of business disruptions and system failure does not necessarily increase operating risk, significantly.

\subsection{Fourth hypothesis: The loss associated with related events within the organization increases operating risk meaningfully.}

Once more, like what we have done in the previous hypothesis we can compute t-student value, which is 2.24>1.96 and this means that we can reject the null hypothesis when the level of significance is five percent. Therefore, null hypothesis is rejected and we can conclude that loss because of related events within the organization increases operating risk, significantly. Table 5 summarizes the results of our survey for four tested hypotheses.

\section{Table 5}

One-Sample Kolmogorov-Smirnov Test (The significance level is five percent)

\begin{tabular}{lcccccc}
\hline Variable & Mean & $\begin{array}{l}\text { Standard } \\
\text { deviation }\end{array}$ & $\begin{array}{l}\text { Standard } \\
\text { error }\end{array}$ & t-student & P-value \\
\hline Events related to the processes and methods & 11.232 & 4.701 & 0.623 & 3.59 & 0.000 \\
Business disruptions and system failure & 11.014 & 4.691 & 0.621 & 3.24 & 0.001 \\
Events outside the organization & 9.682 & 4.975 & 0.659 & 1.04 & 0.153 \\
Related events within the organization & 10.434 & 4.904 & 0.650 & 2.21 & 0.016 \\
\hline
\end{tabular}

Fifth hypothesis: The effects associated with business disruption are more than other events.

Sixth hypothesis: The effects of internal affairs are less than other events.

In order to test these two hypotheses we first do the following test

$$
\begin{aligned}
& \left\{\begin{array}{l}
H_{0}: \mu_{1}=\mu_{2}=\mu_{3}=\mu_{4} \\
H_{1}: \mu_{1} \neq \mu_{2} \neq \mu_{3} \neq \mu_{4}
\end{array}\right. \\
& f(d f: 168,3)=4.898, p=.003
\end{aligned}
$$

As we can observe p-value is very small so we can conclude that at least one of the item is different from the other factors and we need to make bonferroni comparisons among all combinations of variables. Table 6 demonstrates details of our comparisons. Based on the results of Table 6, we realize that the mean of events related to the processes and methods is greater than the mean of events outside the organization but when we compare it with related events within the organization and business disruptions and system failure we do not see any meaningful difference. Details of our findings show that we do not have enough evidence to claim that the effects of business disruption and internal affairs are significantly different from the other event. Therefore, the fifth and sixth hypotheses are not confirmed.

\section{Conclusion}

In this paper, we have presented an empirical study to measure the effects of different factors on operating loss in one of major Iranian banks called Bank Mellat. The proposed study of this paper used a standard questionnaire and distributed it among 57 people. The questions have been categorized into five groups including events related to the processes and methods, events outside the organization, related events within the organization and business disruptions and system failure. The results of our survey confirmed that the loss associated with events related to the processes and 
methods increases operating risk meaningfully, the loss associated with business disruptions and system failure increases operating risk meaningfully and the loss associated with related events within the organization increases operating risk meaningfully. However, our survey did not confirm that the loss associated with events outside the organization increase operating, risk meaningfully. Finally, we did not find enough evidence to believe that the effects of business disruption and internal affairs were significantly different from the other event.

\section{Table 6}

Pairwise comparisons

\begin{tabular}{|c|c|c|c|c|}
\hline First factor & Second factor & Difference with first factor & Standard error & P-value \\
\hline \multirow{3}{*}{$\begin{array}{l}\text { Events related to the } \\
\text { processes and methods }\end{array}$} & Events outside the organization & 1.553 & .412 & .002 \\
\hline & $\begin{array}{l}\text { Related events within the } \\
\text { organization }\end{array}$ & .799 & .376 & .227 \\
\hline & $\begin{array}{l}\text { Business disruptions and system } \\
\text { failure }\end{array}$ & .218 & .509 & 1.000 \\
\hline \multirow[t]{3}{*}{$\begin{array}{l}\text { Events outside the } \\
\text { organization }\end{array}$} & $\begin{array}{l}\text { Events related to the processes } \\
\text { and methods }\end{array}$ & -1.553 & .412 & .002 \\
\hline & $\begin{array}{l}\text { Related events within the } \\
\text { organization }\end{array}$ & -.754 & .420 & .471 \\
\hline & $\begin{array}{l}\text { Business disruptions and system } \\
\text { failure }\end{array}$ & -1.335 & .511 & .069 \\
\hline \multirow[t]{3}{*}{$\begin{array}{l}\text { Related events within } \\
\text { the organization }\end{array}$} & $\begin{array}{l}\text { Events related to the processes } \\
\text { and methods }\end{array}$ & -.799 & .376 & .227 \\
\hline & Events outside the organization & .754 & .420 & .471 \\
\hline & $\begin{array}{l}\text { Business disruptions and system } \\
\text { failure }\end{array}$ & -.581 & .416 & 1.000 \\
\hline \multirow[t]{3}{*}{$\begin{array}{l}\text { Business disruptions } \\
\text { and system failure }\end{array}$} & $\begin{array}{l}\text { Events related to the processes } \\
\text { and methods }\end{array}$ & -.218 & .509 & 1.000 \\
\hline & Events outside the organization & 1.335 & .511 & .069 \\
\hline & $\begin{array}{l}\text { Related events within the } \\
\text { organization }\end{array}$ & .581 & .416 & 1.000 \\
\hline
\end{tabular}

\section{References}

Aquaro, V., Bardoscia, M., Bellotti, R., Consiglio, A., De Carlo, F., \& Ferri, G. (2010). A Bayesian Networks approach to Operational Risk. Physica A: Statistical Mechanics and its Applications, 389(8), 1721-1728.

Chavez-Demoulin, V., Embrechts, P., \& Nešlehová, J. (2006). Quantitative models for operational risk: Extremes, dependence and aggregation. Journal of Banking \& Finance, 30(10), 2635-2658.

Chateau, J.P.D. (2009). Marking-to-model credit and operational risks of loan commitments: A Basel-2 advanced internal ratings-based approach. International Review of Financial Analysis, 18(5), 260-270.

Feng-ge, Y., \& Ping, Z. (2012). The measurement of operational risk based on CVaR: A decision engineering technique. Systems Engineering Procedia, 4, 438-447.

Jiménez-Rodríguez, E.J., Feria-Domínguez, J.M., \& Martín-Marin, J.L. (2011). The regulatory loss cut-off level: Does it undervalue the operational capital at risk? The Spanish Review of Financial Economics, 9(2), 49-54.

Peters, G.W., Shevchenko, P.V., Young, M., \& Yip, W. (2011). Analytic loss distributional approach models for operational risk from the -stable doubly stochastic compound processes and implications for capital allocation. Insurance: Mathematics and Economics, 49(3), 565-579.

Wahlström, G. (2009). Risk management versus operational action: Basel II in a Swedish context. Management Accounting Research, 20(1), 53-68.

Xie, Y., Wu, Y.W., \& Hu, Y.C. (2011). The Engineering of China Commercial Bank Operational Risk Measurement. Systems Engineering Procedia, 1, 330-336. 